УДК 336.77:334.7

\title{
ДОСЛІДЖЕННЯ СУТНОСТІ ПОНЯТТЯ ФІНАНСОВИЙ МОНІТОРИНГ
}

Бормотова М.В., к.е.н, доцент,

Мухіна К. О., студентка (УкрДУЗТ)

У сучасних умовах ринку Україна з ї̈ потужним потенціалом, не могла не зіткнутися 3 проблемою "відмивання" коштів, одержаних злочинним шляхом. Центральною ланкою у комплексі заходів запобігання та протидії відмиванню коштів є фінансовий моніторинг. У статті проаналізовані існуючи визначення поняття "фінансовий моніторинг". Обгрунтовано авторське визначення поняття "фінансовий моніторинг".

Ключові слова: моніторинг, фінансовий моніторинг, легалізація доходів, первинний фінансовий моніторинг, державний моніторинг, суб'єкти моніторингу.

\section{ИССЛЕДОВАНИЯ СУЩНОСТИ ПОНЯТИЯ ФИНАНСОВИЙ МОНІТОРИНГ}

\author{
Бормотова М.В., к.э.н, доцент, \\ Мухина Е.А., студентка (УкрГУЖТ)
}

\begin{abstract}
В современных условиях рынка Украины с ее мощңным потенциалом, не могла не столкнуться с проблемой "отмывания" средств, полученных преступным путем. Центральным звеном в комплексе мер предупреждения и противодействия отмыванию средств является финансовый мониторинг. B статье проанализированы существуюшие определения понятия "финансовый мониторинг". Обосновано авторское определение понятия "финансовый мониторинг".
\end{abstract}

Ключевые слова: мониторинг, финансовый мониторинг, легализация доходов, первичный финансовый мониторинг, государственный мониторинг, субъекты мониторинга.

\section{STUDY ESSENCE OF CONCEPT OF FINANCIAL MONITORING}

\author{
Bormotova M.V., Candidate of Economic Sciences, associate professor \\ Mukhina K.O, student (Ukrainian State University of Railway Transporte)
}

Revenues from crime constitute a serious threat to legitimate economic activity, destabilize existing financial and monetary systems, reduced welfare, filling the state budget. In Ukraine at the legislative level system formed the prevention of crime and other offenses related to the legalization of proceeds from crime, and created by agencies and departments, which was empowered to control financial flows, combat and combat "money." But to date there is still no single point of view on the definition of the concept of the essence of financial monitoring.

Some authors consider a financial monitoring system, others - as a set of measures. Some of the narrow scope of the definition of financial monitoring of banks only or only for businesses.

The article analyzed the existing definition of "financial monitoring". Copyright grounded definition of "financial monitoring" which covers all levels of financial monitoring are adequate, and at the same time brief.

Keywords: monitoring, financial monitoring, legalization of incomes, primary financial monitoring, state monitoring,. monitoring entities.

Постановка проблеми та її зв'язки 3 науковими чи практичними завданнями. Сьогодні в Україні питання, пов'язані 3 фінансовим моніторингом доходів, отриманих злочинних шляхом, набули великої актуальності і перебувають у центрі уваги нашого суспільства. Актуальність даної проблеми полягає в тому, що припинення отримання доходів в тіньовому секторі економіки дозволить значно збільшити податкові надходження до Державного бюджету, що особливо необхідно в умовах значного дефіциту бюджету України. Доходи, отримані злочинним шляхом, становлять серйозну небезпеку для законної економічної діяльності, дестабілізації існуючих фінансової та валютної систем, зниження добробуту населення, наповнення державного бюджету. В Україні на законодавчому рівні сформована система запобігання злочинам та іншим правопорушенням, пов'язаними 3 легалізацією коштів, здобутих злочинним шляхом, створені і визначені органи та підрозділи, на які покладено функції щодо 
контролю за фінансовими потоками, протидії та боротьби з "відмиванням".

Аналіз останніх досліджень i публікацій. Вагомий внесок у розроблення теоретичних і практичних засад фінансового моніторингу внесли такі зарубіжні та вітчизняні вчені: А. Клименко [1], Л. Воронова [2], А. Гаврилишин [3], I. Патюта [4], Б. Сюркало [5], О. Костюченко і К. Кривуля [6], Ж. Довгань [7], Г. Бірюков [8], О. Орлюк [9], В. Берізко [10], М. Прошунін [11].

Виділення невирішених частин загальної проблеми. На сьогоднішній день досі немає єдиної точки зору щодо визначення сутності поняття фінансовий моніторинг. Це $\epsilon$ актуальним питанням, яке потребує докладного вивчення.

Метою статті є дослідження та уточнення визначення поняття фінансовий моніторинг. дослідження.

Виклад основного матеріалу

У сучасних умовах ринку Україна 3 іï потужним потенціалом, не могла не зіткнутися 3 проблемою "відмивання" коштів, одержаних злочинним шляхом. В Україні після здобуття незалежності, а також і в багатьох інших країна
СНД, дуже швидко зросла "тіньова" економіка. Це було зумовлено непідготовленістю до корінних перетворень в економіці, i, насамперед, відсутністю належного правового забезпечення фінансового моніторингу. Центральною ланкою у комплексі заходів запобігання та протидії відмиванню коштів $\epsilon$ фінансовий моніторинг. Поняття "моніторинг" вивчається i використовується в межах різних сфер науковопрактичної діяльності. 3 англ. моnitoring означає постійне спостереження за яким-небудь процесом 3 метою виявлення його відповідності бажаному результату або тенденцій розвитку. Єдиного визначення поняття "моніторинг" в економічній літературі не існує. Його тлумачення залежить від сфери застосування i напряму наукових досліджень. Відсутність єдиного погляду $\epsilon$ наслідком недосконалості законодавства, що встановлює основні підходи до організації та здійснення моніторингу як методу контролю.Також не їснує єдиної точки зору щодо визначення поняття "фінансовий моніторинг".

Визначення поняття "фінансовий моніторинг" різними вченими наведено в таблиці 1.

Таблиия 1

Визначення понятття "фінансовий моніторинг"

\begin{tabular}{|c|c|}
\hline Автор & Визначення \\
\hline 1 & 2 \\
\hline А.Клименко [1] & $\begin{array}{l}\text { Особлива форма фінансового контролю, яка здійснюється уповноваженими } \\
\text { державними органами у сфері фінансового контролю та суб'єктами первинного } \\
\text { фінансового моніторингу та спрямована на виявлення операцій, пов'язаних } 3 \\
\text { легалізацією доходів, здобутих злочинним шляхом. }\end{array}$ \\
\hline Л.Воронова [2] & $\begin{array}{l}\text { Особлива форма фінансового контролю як окремий інститут фінансового права, що } \\
\text { передбачає управління фінансами, яке містить усі елементи механізму фінансового } \\
\text { контролю у їх зовнішньому вияві. }\end{array}$ \\
\hline А.Гаврилишин[3] & $\begin{array}{l}\text { Сукупність заходів суб'єктів фінансового моніторингу з метою виявлення, аналізу та } \\
\text { перевірки інформації про фінансові операції щодо віднесення їх до таких, що можуть } \\
\text { бути пов'язані } 3 \text { легалізацією (відмиванням) доходів незаконного походження } 3 \\
\text { наступним переданням їх правоохоронним органам. }\end{array}$ \\
\hline I. Патюта [4] & $\begin{array}{l}\text { Передбачає постійне спостереження, що дає можливість прогнозувати випадки } \\
\text { ризиків пов’язаних з легалізацією коштів. }\end{array}$ \\
\hline Б. $\mathrm{C}$ & $\begin{array}{l}\text { Складова системи фінансового планування банку, на основі якої формується єдина } \\
\text { база даних планування діяльності при безперервному зборі, систематизації та } \\
\text { обробці інформації. }\end{array}$ \\
\hline $\begin{array}{l}\text { О.Костюченко } \\
\text { К. Кривуля [6] }\end{array}$ & $\begin{array}{l}\text { Система заходів по здійсненню постійного спостереження за діяльністю } \\
\text { комерційного банку, збору і систематизації даних про його фінансовий стан для } \\
\text { оцінки поточного стану справ у банківській сфері і прогнозування його розвитку на } \\
\text { перспективу. }\end{array}$ \\
\hline Ж. Довган & $\begin{array}{l}\text { Система, яка включає сукупність елементів, що взаємодіють і перебувають під дією } \\
\text { внутрішніх і зовнішніх факторів. яка охоплює спостереження за рівнем стійкості } \\
\text { банку, аналіз, оцінку і прогнозування стійкості на довгострокову перспективу. }\end{array}$ \\
\hline Г. Бірюкс & 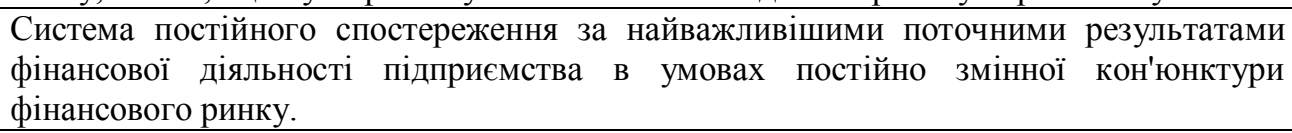 \\
\hline
\end{tabular}


Продовження табл1.

\begin{tabular}{|c|c|}
\hline 1 & 2 \\
\hline О. Орлюк [9] & $\begin{array}{l}\text { Фінансовий моніторинг - це специфічна форма державного фінансового контролю, який } \\
\text { проводять уповноважені державні органи та установи, що обслуговують здійснення } \\
\text { фінансових операцій, відстежують та фіксують фінансові операції, які відповідають, згідно } \\
3 \text { Законом України «Про запобігання та протидію легалізаці (відмиванню) доходів, } \\
\text { одержаних злочинним шляхом», критеріям сумнівності, аналізують одержану інформацію } \\
\text { про сумнівні операції з метою виявлення схем та механізмів легалізації доходів, } \\
\text { одержаних злочинним шляхом, і фінансування терроризму. }\end{array}$ \\
\hline В. Берізко [10] & $\begin{array}{l}\text { Фінансовий моніторинг - це сукупність заходів суб’єктів фінансового моніторингу } 3 \\
\text { метою виявлення, аналізу та перевірки інформації про фінансові операції на предмет } \\
\text { віднесення їх до таких, що можуть бути пов'язані з легалізацією (відмиванням) доходів } \\
\text { незаконного походження для передання ії правоохоронним органам. }\end{array}$ \\
\hline М. Прошунін[11] & $\begin{array}{l}\text { Фінансовий моніторинг є системою законодавчо закріплених інформаційних, контрольних } \\
\text { і правоохоронних процедур, здійснюваних органами й агентами, мета яких полягає у } \\
\text { запобіганні використання фінансової системи для легалізації злочинних доходів та } \\
\text { фінансування тероризму і мінімізації ризику причетності агентів фінансового моніторингу } \\
\text { до легалізації (відмивання) злочинних доходів та фінансування терроризму. }\end{array}$ \\
\hline
\end{tabular}

Фінансовий моніторинг як система розглядається такими авторами: І. Бірюкова, Ж. Довгань, К. Костюченко, О. Кривуля, Б. Сюркало. А такий вчений як А. Гаврилишин розглядає фінансовий моніторинг як комплекс заходів. К. Костюченко, О. Кривуля, Б. Сюркало звужують сферу визначення фінансового моніторингу тільки для діяльності банків, а Г. Бірюков - для підприємств. Це не зовсім вірно, тому що фінансовий моніторинг містить два рівні первинний i державний. Суб'єктами первинного фінансового моніторингу виступають банки, страхові компанії, фінансові установи, інститути спільного інвестування та інші. Також не можна підтримати думку вчених О. Орлюка i A. Клименко, які стверджують, що фінансовий моніторинг є специфічною формою державного фінансового контролю, що виключає вищеназваних суб'єктів первинного фінансового моніторингу. Отже проаналізувавши визначення фінансового моніторингу, можна сформулювати узагальнене поняття: фінансовий моніторинг - це система фінансового контролю, спрямована на протидію й запобігання легалізації грошей та іншого майна, отриманих злочинним шляхом як в окремих суб'єктах господарювання, так і в масштабі всієї країни. Це визначення охоплює усі рівні фінансового моніторингу, $є$ достатньо повним, i в той же час лаконичним. Таке визначення фінансового моніторингу дозволяє комплексно врахувати його змістовну сутність.

Висновки даного дослідження i перспективи подалыших робіт у цьому напрямку. Таким чином, в роботі проведений аналіз сутності поняття "фінансовий моніторинг" та обгрунтовано авторське визначення. Подальші дослідження повинні бути зосереджені на узагальненні складових елементів системи фінансового моніторингу.

\section{СПИСОК ЛІТЕРАТУРИ}

1. Клименко А. О. Організаційно-правові засади діяльності банків в системі заходів протидії легалізації доходів, здобутих злочинним шляхом: Автореф. дис. ... канд. юрид. наук: 12.00.08 /Національна академія внутрішніх справ України. - К., 2004. - C 19.

2. Фінансове право України: навч. посібник [для. студ. вищ. навч. закл.] / Воронова Л. К. - К. : Прецедент ; Моя книга, 2007. - 448 с [Л. К. Воронова, М. П. Кучерявенко, Н. Ю. Пришва та. ін.]. - К. : Правова єдність, 2009. 395 с.

3. Гаврилишин А. П. Щодо питання понятійного апарату "фінансовий моніторинг" / А. П. Гаврилишин // Організаційно-правове забезпечення діяльності контролюючих та правоохоронних органів у сфері господарювання : проблеми сьогодення i перспективи розвитку: матеріали всеукраїнської науково-практичної конференції. - Ірпінь: Національний університет ДПС України, 2008. - 588 с.

4. Сучасні схеми і підходи до легалізації (відмивання) доходів, одержаних злочинним шляхом у банківському секторі України / I. М. Патюта //Актуальні проблеми економіки. - 2012. № 6. - С. 262-269

5. Напрями вдосконалення системи державного фінансового моніторингу. Б. Сюркало, // Електронне наукове фахове видання /"Ефективна економіка". Дніпропетровський державний аграрно економічний університет. -2013 - № 3. - С. 241-244

6. Правові умови та шляхи вдосконалення
системи фінансового моніторингу в
банку [Електронний ресурс] / О. С. Костюченко, К.
А. Кривуля // Економічні науки. Сер. : Облік і
фінанси. - 2012. - Вип. 9(4). - С. 205-214.
7. Довгань Ж. Індикатори та моніторинг
фінансової стійкості банківської системи / Ж.
Довгань // Вісник Тернопільського національного


економічного університету. - 2011. - № 2. - С. 3141.

8. Бірюкова I. Г. Основні проблеми фінансового моніторингу у протидії легалізації (відмиванню) доходів, одержаних злочинним шляхом / I. Г. Бірюкова // Науковий вісник Національного університету ДПС України (економіка, право). - 2012. - № 1(56). - С. 235-241.

9. Орлюк О. П. Фінансове право. Академічний курс : підручник / Орлюк О. П. - К. : Юрінком Інтер, 2010

10. Берізко В. М. Щодо питання понятійного апарату „фінансовий моніторинг” / В.
М. Берізко // Право України. - 2006. - № 12. - С. $52-53$.

11. Прошунин M. М. Финансовый мониторинг в системе противодействия легализации преступных доходов и финансированию терроризма (российский и зарубежный опыт) : автореф. дисс. на соиск. учен. степ. докт. юрид. наук : спец. 12.00.14 Административное право, финансовое право, информационное право / М. М. Прошунин. Москва, 2010. - 44 с.

Рецензент д.е.н., професор УкрДУЗТ Зайцева І.Ю. Експерт редакційної колегії к.е.н., дочент УкрДУЗТ Шраменко О.В.

УДК 330

\title{
ОСНОВНЫЕ СРЕДСТВА: ПРОБЛЕМЫ ХАРАКТЕРИСТИКИ НАЛИЧИЯ, ДВИЖЕНИЯ, КЛАССИФИКАЦИИ И ОЦЕНКИ ЭФФЕКТИВНОСТИ ИСПОЛЬЗОВАНИЯ
}

\author{
Вовк А.А., д.э.н., профессор (МИИТ) \\ Вовк Ю.А., к.э.н., руководитель отдела (ОАО «РЖД») \\ Чуприкова 3.В., к.э.н., доцент (МИИТ)
}

В статье раскрывается сущность понятий «основные средства» $и$ «основнье фондыл», предлагаются принципы характеристики их размера и движения основных средств, рассматриваются вопросы их классификации и оценки эффективности использования. Целью статьи является раскрытие сущьности категорий «основные средства» и «основныле фонды», с тем, чтобы в результате этого обосновать подход к характеристике наличия орудий труда, их движения, классификачии, а также оценке эффективности использования, опираясь на научное раскрытие их сущности. Сделан вывод, что понятие «основные средства» правомерно применять для обобщающего наименования орудий труда, имеющих вещественное выражение и характеризовать его количеством инвентарньх объектов. В то же время понятие «основные фонды» правомерно применять как синоним понятия «основной капитал». Для оценки эффективности использования активных основных средств следует ввести понятие «полезный результат», который будет характеризовать то, что создано в прочессе использования данного вида основных средств. Оченку эффективности использования пассивных основньх средств следует осуществлять на основе размера произведенной продукиии организации. На основе полученньх результатов следует рассчитывать обобщающий показатель отдачи основных средств по продукиии.

Ключевые слова: основные фонды, основные средства, эффективность использования основных фондов, полезный результат, основной капитал.

\section{ОСНОВНІ ЗАСОБИ: ПРОБЛЕМИ ХАРАКТЕРИСТИКИ НАЯВНОСТІ, РУХУ, КЛАСИФІКАЦІЇ ТА ОЦНКИ ЕФЕКТИВНОСТІ ВИКОРИСТАННЯ}

\author{
Вовк О.O., д.е.н., професор (MIIT) \\ Вовк Ю.О. к.е.н., керівник відділу (ВАТ «РЖД») \\ Чуприкова 3.В. к.е.н., доцент (МІІТ)
}

\begin{abstract}
У статті розкривається сутність понять «основні засоби» та «основні фонди», пропонуються принципи характеристики їх розміру та руху основних засобів, розглядаються питання їх класифікації та оцінки ефективності використання. Метою статті є розкриття сутності категорій «основні засоби» та
\end{abstract}

(C) Вовок А.А.,

Вовк Ю.А.,

Чуприкова 3.В.

Вісник економіки транспорту і промисловості № 49, 2015 